Jurnal Kesmas Asclepius

Volume 2, Nomor 1, Juni 2020

e-ISSN: 2684-8287

p-ISSN: 2656-8926

DOI: https://doi.org/10.31539/jka.v2i1.585

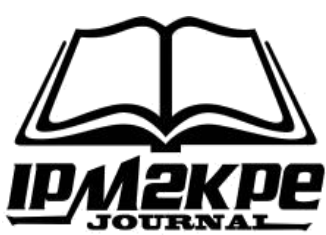

\title{
PACAR BERHUBUNGAN DENGAN PERILAKU SEKS PRANIKAH PADA REMAJA
}

\author{
Siti Qomariah \\ Universitas Abdurrab \\ siti.qomariah@univrab.ac.id
}

\begin{abstract}
ABSTRAK
Tujuan penelitian ini adalah untuk mengetahui hubungan pacar terhadap perilaku seksual pada remaja di SMP Negeri 16 Kecamatan Sukajadi Pekanbaru. Metode Penelitian yang digunakan bersifat kuantitatif analitik observasional (cross-sectional). Hasil analisis univariat mayoritas responden berumur 12 tahun. Jenis kelamin mayoritas perempuan dan beragama islam, mayoritas berperilaku seks negatif. Hasil analisis bivariat didapatkan hasil nilai $p$-value $(0,000)<a=0,05$. Simpulan, ada hubungan pacar terhadap perilaku seks pra nikah pada remaja di SMP Negeri 16 Kecamatan Sukajadi Pekanbaru.
\end{abstract}

Kata Kunci : Perilaku, Remaja, Seks Pranikah

\section{ABSTRACT}

This study aimed to determine the relationship of boyfriends to sexual behavior in adolescents in SMP Negeri 16 Sukajadi subdistrict Pekanbaru. The research method used is analytic quantitative observational (cross-sectional). The results of the univariate analysis of the majority of respondents aged 12 years amounted. The majority of the sexes are women and are Muslim; the majority behave negatively. Bivariate analysis results obtained p-value $(0,000)<a=0.05$. In conclusion, there is a relationship of boyfriends to premarital sexual behavior among teenagers in SMP Negeri 16 Kec. Sukajadi Pekanbaru.

Keywords: Behavior, Teenagers, Premarital Sex

\section{PENDAHULUAN}

Masa remaja adalah masa peralihan dari kanak-kanak menuju dewasa, pada masa itu terjadi pertumbuhan pesat termasuk fungsi reproduksi sehingga mempengaruhi terjadinya perubahan perkembangan, baik fisik, mental, maupun peran sosial (Febriawati et al., 2018). Karakteristik perkembangan remaja, salah satunya adalah memiliki rasa ingin tahu tinggi yang membuat remaja cenderung ingin berpetualang, menjelajah, dan mencoba segala sesuatu yang belum pernah dialaminya (Santrock, 2010).

Masa remaja merupakan periode terjadinya pertumbuhan dan perkembangan yang pesat baik secara fisik, psikologis, maupun intelektual. Sifat khas remaja yang memiliki rasa keingintahuan yang besar, menyukai petualangan dan tantangan serta cenderung berani menanggung risiko tanpa pertimbangan yang matang, salah satu permasalahan yang terjadi pada masa remaja adalah perilaku seks pranikah. Perilaku seksual pranikah merupakan salah satu akibat dari pergaulan bebas (Kemenkes RI, 2015). 
Menurut hasil sensus penduduk tahun 2010, jumlah peduduk Indonesia sebanyak 237,6 juta jiwa dimana 26,7\% diantaranya remaja. Remaja yang berumur 15-24 tahun berjumlah 40,75. Sementara jumlah penduduk 10-14 tahun berjumlah 22,7 juta. Besarnya penduduk remaja berusia 10-24 tahun perlu mendapat perhatian serius karena remaja termasuk dalam usia sekolah dan usia kerja. Remaja sangat berisiko terhadap masalah kesehatan reproduksi diantaranya adalah perilaku seksual pranikah, napza dan HIV/AIDS (Agustina, 2013).

Perilaku seksual remaja, terutama perilaku seks pranikah adalah masalah serius yang merupakan faktor risiko terpenting bagi timbulnya kecacatan dan kematian di negara-negara miskin. Hubungan seks pranikah pada remaja mengalami peningkatan selama abad ke-20. Hasil Survey Kesehatan Reproduksi Remaja Indonesia (SKRRI) tahun 2007 menunjukkan sebesar 6,4\% remaja laki-laki dan 1,3\% remaja telah melakukan hubungan seks pranikah (Rahyani et al., 2012).

Menurut World Health Organization (WHO) sekitar seperlima dari penduduk dunia merupakan remaja berumur 10-19 tahun dan sekitar 900 juta berada di negara sedang berkembang. Selain itu data demografi di Amerika Serikat menunjukkan jumlah remaja berumur 10-19 tahun sekitar 15\% populasi. Di Asia Pasifik jumlah penduduknya $60 \%$ dari penduduk dunia, seperlimanya merupakan remaja umur 10-19 tahun (Nurhayati \& Fajar, 2017).

Survei RPJMN Remaja dari tahun 2012- 2014 menggunakan responden remaja berumur 15-24 tahun belum menikah yang dilakukan di Sulawesi Utara. Hasil penelitian menunjukkan $90 \%$ remaja yang berpacaran pernah berpegangan tangan. Sementara remaja berpacaran yang mengaku pernah ciuman bibir pada 2014 mencapai 59\%. Menurut BKKBN, angka ini menurun dibanding tahun 2013 yakni 63\%. Namun, masih tinggi dibandingkan data 2012, dimana ada $39 \%$ remaja pernah berciuman bibir. Aktivitas ini yang teramat membahayakan karena bisa menjurus ke hal-hal yang serius seperti perilaku seksual di luar pernikahan (Agung, 2016; Hamzah \& Hamzah, 2020).

Dari beberapa penelitian diketahui bahwa perilaku pacaran akan meningkatkan risiko terjadi hubungan seksual pranikah karena di dalam perilaku pacaran diketahui terjadi aktivitas dengan lawan jenis baik itu terjadi kontak fisik maupun tidak kontak fisik (Rahyani et al., 2012).

Perilaku seksual remaja dalam berpacaran adalah manifestasi dorongan seksual yang diwujudkan mulai dari melirik ke arah bagian sensual pasangan sampai bersenggama yang dilakukan oleh remaja yang sedang berpacaran. Aktivitas seksual seolah-olah sudah menjadi hal yang lazim dilakukan oleh remaja yang berpacaran (Rusmiati \& Hastono, 2015).

Faktor-faktor timbulnya masalah seksualitas pada remaja antara lain perubahanperubahan hormonal yang meningkatkan hasrat seksual (libido seksualitas) remaja. Peningkatan hasrat seksual ini membutuhkan penyaluran dalam bentuk tingkah laku seksual tertentu. penyaluran itu tidak dapat segera dilakukan karena adanya penundaan usia perkawinan. Sementara usia kawin ditunda, norma-norma agama tetap berlaku (Rahyani et al., 2012).

Ciri khas kematangan psikologis ini ditandai dengan ketertarikan terhadap lawan jenis yang biasanya muncul dalam bentuk misalnya lebih senang bergaul dengan lawan jenis dan sampai pada perilaku yang sudah menjadi kosumsi umum, yaitu berpacaran. Pacaran itu sendiri sebenarnya adalah suatu proses alami yang dilalui remaja untuk mencari seorang teman akrab yang didalamnya terdapat hubungan dekat dalam berkomunikasi, membangun kedekatan emosi dan proses pendewasaan kepribadian 
(Musthofa, 2010).

Ironisnya adalah sesuatu yang baik itu biasanya sulit untuk diterima demikian sebaliknya sesuatu yang buruk dan menyesatkan biasanya sangat mudah diadopsi oleh remaja, hal ini termasuk informasi tentang seksual tanpa batas. Tidak sedikit informasi yang diperoleh remaja disalahartikan sehingga menimbulkan berbagai perilaku menyimpang yang akibatnya tidak saja merugikan remaja itu sendiri, tetapi juga dapat merugikan orang lain, seperti melakukan hubungan seks dengan pacar tanpa memperhitungkan akibat yang timbul, yaitu kehamilan (Azinar,2013)

Usia remaja sebanyak 2,6\% usia perkawinan pertama berada pada kelompok usia kurang dari 15 tahun, 23,9\% berada pada kelompok usia 15-19 tahun. Kehamilan pada umur kurang 15 tahun sebanyak 0,02\% dan kehamilan pada umur remaja (15-19 tahun) sebesar 1,97\%. Jumlah remaja umur 10-24 tahun di Indonesia sekitar 64 juta atau 28,64\% dari jumlah penduduk. Sekitar 1 juta remaja pria (5\%) dan 200 ribu remaja wanita (1\%) menyatakan secara terbuka bahwa mereka pernah melakukan hubungan seksual. Hal ini menunjukkan bahwa perilaku seks beresiko terjadi pada usia remaja.

Hal ini sesuai dengan pernyataan Fuad (2010) direktur remaja dan perlindungan hak-hak reprodukssi bahwa $63 \%$ remaja Indonesia pernah melakukan seks bebas. Data lain menunjukkan, dari 385 remaja $18,4 \%$ nya menyatakan telah melakukan hubungan seksual pra nikah. Lebih parah lagi, 53,5\% menyatakan motivasinya adalah sekedar cobacoba. Sedangkan yang disebabkan oleh cinta 23,9\% dan karena desakan kebutuhan biologis sebesar $14,1 \%$.

Tingginya kejadian hubungan seks pranikah pada remaja menurut berbagai penelitian ada bermacam-macam faktor. Faktor-faktor yang mempengaruhi remaja melakukan hubungan seksual pranikah yaitu adanya dorongan biologis, pemberian fasilitas (termasuk uang) pada remaja secara berlebihan, pergeseran nilai-nilai moral dan etika di masyarakat, serta kemiskinan mendorong terbukanya kesempatan bagi remaja khususnya wanita untuk melakukan hubungan seks pranikah.

\section{METODE PENELITIAN}

Penelitian yang digunakan bersifat kuantitatif analitik observasional (crosssectional) dengan unsur variabel independen dan dependen. Populasi dalam penelitian ini adalah seluruh siswa-siswi SMPN 16 di Kecamatan Sukajadi Pekanbaru. Sampel ini adalah siswa-siswi SMPN 16 di Kecamatan Sukajadi Pekanbaru dengan jumlah sampel 186 responden.

Pengambilan sampel dilakukan secara total sampling. Data yang digunakan adalah data primer dengan menyebarkan kuesioner. Analisis data dilakukan secara univariat, bivariat dengan uji chi-square.

\section{HASIL PENELITIAN Analisis Univariat}

Tabel. 1

Distribusi Frekuensi Analisis Univariat Karakteristik Responden

\begin{tabular}{lcc}
\hline \multicolumn{1}{c}{ Variabel } & Frekuensi & $\%$ \\
\hline Jenis Kelamin & & \\
Laki-laki & 62 & 33.3 \\
Perempuan & 121 & 65.1 \\
\hline
\end{tabular}




\begin{tabular}{lcc}
\hline Umur & & \\
12tahun & 95 & 51.1 \\
13tahun & 88 & 47.3 \\
\hline Agama & & \\
Islam & 133 & 71.5 \\
Kristen Protestan & 9 & 4.8 \\
KristenKatolik & 41 & 22.0 \\
\hline Perilaku Seks & & \\
Negatif & 100 & 53.8 \\
Positif & 83 & 44.6 \\
\hline \multicolumn{1}{c}{ Jumlah } & 186 & 100 \\
\hline
\end{tabular}

Berdasarkan tabel diatas karakteristik umur responden mayoritas berumur 12 tahun berjumlah $95(51,1 \%)$. Perempuan berjumlah 121 orang $(65,1 \%)$, mayoritas agama islam berjumlah $133(71,5 \%)$, mayoritas berperilaku seks negatif berjumlah 100 orang $(53.8 \%)$.

\section{Analisis Bivariat}

Tabel. 2

Distribusi Faktor-Faktor yang Mempengaruhi Perilaku Seks Pranikah

\begin{tabular}{|c|c|c|c|c|c|}
\hline \multirow{3}{*}{ Pengetahuan } & \multicolumn{4}{|c|}{ Perilaku Seks } & \multirow{3}{*}{ P Value } \\
\hline & \multicolumn{2}{|c|}{ Negatif } & \multicolumn{2}{|c|}{ Positif } & \\
\hline & $\mathrm{N}$ & $\%$ & $\mathrm{~N}$ & $\%$ & \\
\hline Kurang & 38 & 67,9 & 18 & 32,1 & 0,000 \\
\hline Baik & 62 & 48,8 & 47 & 51,2 & \\
\hline
\end{tabular}

Pada table 2 dapat diketahui bahwa ada hubungan pacar terhadap perilaku seks pra nikah pada remaja di SMP Negeri 16 Kecamatan Sukajadi.

\section{PEMBAHASAN}

Banyaknya kasus kehamilan, aborsi dan penyakit kelamin akibat hubungan seks bebas pada remaja, diperoleh kesimpulan bahwa kebanyakan menjadi korban karena ketidaktahuannya mengenai seks dan sebagian besar dari mereka dilakukan dengan teman akrab (pacar).

Penelitian yang dilakukan Evi et al., (2013) menyatakan pacaran sehat dipersepsikan informan sebagai aktivitas duduk berkomunikasi dengan pasangan, komunikasi melalui handphone tanpa ada yang mengarah ke hubungan seksual. Sedangkan pacaran tidak sehat apabila seseorang sering keluar malam bersama pacar dan telah melakukan tindakan yang mengarah, bahkan hingga melakukan hubungan seksual sebelum adanya ikatan pernikahan. Hasil penelitian Kisriyati menyebutkan bahwa persepsi tentang cinta yang mengarah pada keadaan saling memberi dan saling menerima (Kisriyati, 2013).

Penelitian Meilani \& Setiyawati (2017) didapatkan hasil bahwa perilaku pacaran yang terjadi pada responden yaitu siswa SMAlebih besar proporsinya pada responden berjenis kelamin laki-laki. Sesuai dengan beberapa penelitian yang menyebutkan bahwa laki-laki lebih berisiko dalam perilaku seksual berisiko dibandingkan perempuan. Proporsi pacaran pada siswa SMA di Yogyakarta hampir sama dengan penelitian di Semarang yang menyatakan siswa yang berpacaran tetapi tidak berisiko atau melakukan 
pacaran tanpa melakukan kontak fisik masih memiliki proporsi yang lebih besar. Namun demikian dengan meningkatnya perilaku pacaran pada remaja akan meningkatkan risiko terjadinya hubungan seksual pranikah karena dalam pacaran remaja tidak hanya berusaha mengenal lawan jenisnya, tetapi sudah sampai melakukan kontak fisik seperti berciuman bahkan lebih (Guruh, 2015).

Dari beberapa penelitian diketahui bahwa perilaku pacaran akan meningkatkan risiko terjadi hubungan seksual pranikah karena di dalam perilaku pacaran diketahui terjadi aktivitas dengan lawan jenis baik itu terjadi kontak fisik maupun tidak kontak fisik. Perilaku pacaran dimulai dari sekedar berkencan, merayu, menggoda, bersentuhan, berciuman, menstimulus organs seks hingga memaksa melakukan hubungan seksual. Sebagian besar responden menyatakan bahwa pacaran tidak akan banyak membantu dalam mencapai kebahagiaan pernikahan (Rahyani et al., 2012; Padila, 2015; Pratiwi et al., 2019).

Dalam penelitian ini diketahui bahwa tingkat pengetahuan tentang kesehatan reproduksi remaja berhubungan dengan perilaku pacaran. Hal tersebut senada dengan beberapa penelitian yang menyatakan bahwa adanya hubungan antara kesehatan reproduksi dengan perilaku pacaran. Demikian pula dengan perilaku seksual pranikah yang diantaranya disebabkan karena kurangnya informasi yang benar tentang kesehatan reproduksi. Karena informasi yang biasa diakses oleh remaja justru informasi yang kurang tepat yang justru mengarah pada akses pornografi. Akses pornografi merupakan stimulus seorang remaja dalam meningkatnya risiko hubungan seksual pranikah (Guruh, 2015; Shahuliyah et al., 2017).

Kurangnya pemahaman tentang seks pranikah ini akan mengakibatkan berbagai dampak yang amat merugikan kelompok remaja dan keluarganya. Pacaran tanpa melakukan hubungan seks itu tidak mengasyikkan dan tidak ada rasa memiliki bahkan jika kebutuhan biologis tersebut tidak dipenuhi oleh salah satu pasangan ketika ada pasangan yang menginginkan hal tersebut maka salah satu pasangan akan marah dan hal ini secara tidak langsung akan mempengaruhi kehidupan seksualitas mereka sebagai seorang remaja. Keinginan remaja untuk melakukan seks pranikah tergantung dari individu tersebut dalam memegang teguh agamanya (Rosdarni \& Dasuki, 2015).

Pengetahuan yang remaja yang kurang mengetahui tentang perilaku seks pranikah, maka sangatlah mungkin jika membuat mereka salah dalam bersikap dan kemudian mempunyai perilaku terhadap seksualitas. Perilaku seksual remaja kota Semarang tahun 2010 aktivitas pacaran yang sampai dengan intercourse 14,1\% dibanding dengan cara yang lain, usia pertama kali melakukan intercourse, presentasi paling besar adalah pada usia 18 - 20 tahun. Pasangan yang melakukan hubungan seksual intercourse lebih dari 4 kali pada 3 bulan terakhir $45 \%$, tempat melakukannya $41 \%$ di rumah sendiri atau pacar, alasan melakukan intercourse karena wujud ungkapan sayang dengan pacar 51\% (PKBI Semarang. 2011).

Perilaku seksual di kalangan remaja saat ini memang mengkhawatirkan, tidak sedikit remaja di Indonesia yang memiliki perilaku seksual berisiko khususnya dalam berpacaran. Padahal, banyak dampak buruk dari perilaku seks berisiko tersebut dan cenderung bersifat negatif, diantaranya adalah kehamilan di luar nikah, aborsi, dan infeksi menular seksual. Dampak tersebut tidak saja dirasakan oleh remaja itu sendiri tapi lebih luas akan berdampak negatif bagi keluarga, masyarakat, dan bangsa pada akhirnya (Lestari, 2016). 
Terjadinya perilaku seksual pada remaja salah satunya dipengaruhi oleh perubahan pandangan yang tampak saat remaja mulai memasuki masa pacaran. Masa pacaran telah diartikan menjadi masa untuk belajar melakukan aktivitas seksual dengan lawan jenis, mulai dari ciuman ringan, ciuman maut, saling masturbasi, seks oral, bahkan sampai hubungan seksual. Berdasarkan hasil survei kesehatan reproduksi remaja yang diselenggarakan BKKBN tahun 2010 perilaku pacaran permisif yang dilakukan oleh remaja antara lain berpegangan tangan saat pacaran (92\%), berciuman (82\%), rabaan petting (63\%) (Ningtyas, 2012).

Beberapa faktor yang berperan terhadap aktifitas perilaku seksual pranikah remaja adalah pengetahuan tentang kesehatan reproduksi, IMS dan HIV/AIDS, sikap mengenai seksualitas, dan pengaruh teman sebaya, namun pengetahuan tentang kesehatan reproduksi beberapa penelitian menemukan hasil yang berbeda. Hasil penelitian yang dilakukan di Kota Kendari dengan jumlah sampel sebanyak 200 remaja dari empat sekolah negeri, menemukan remaja yang memiliki pengetahuan yang rendah tentang kesehatan seksual, IMS dan HIV/AIDS berisiko sebesar 4,28 kali untuk melakukan perilaku seksual pranikah berisiko (Rosdarni \& Dasuki, 2015).

Menurut Sarwono secara garis besar perilaku seksual pada remaja disebabkan oleh beberapa faktor diantaranya adalah kurangnya informasi tentang seks. Remaja yang sudah mulai berkembang kematangan seksualnya secara lengkap jika hal ini kurang mendapat pengarahan dari orang tua maka pengendalian perilaku seksual akan sulit. Mereka sulit mengendalikan rangsangan rangsangan dan banyak kesempatan seksual melalui media masa yang membuat mereka melakukan perilaku seksual secara bebas (Sarwono, 2011; Sarwono \& Sarlito, 2015).

Pada tahap perkembangan remaja rasa ingin tahu mengenai berbagai hal akan timbul dan remaja akan mencoba hal-hal baru yang tidak ia ketahui, selain itu remaja tidak dapat berfikir secara kritis dan terlalu mengedepankan ego serta keingintahuannya tanpa mengerti dampak dan resiko terhadap suatu hal yang akan ia lakukan, jika tidak ada pengawasan dari orang tua dan tidak ada kegiatan yang positif bagi remaja, maka remaja akan terjerumus kepada hal-hal yang negative seperti merokok, minum-minuman beralkohol dan perilaku seks pranikah yang pada akhirnya menimbulkan kerugian bagi remaja itu sendiri, disamping itu kondisi lingkungan sangat berpengaruh terhadap perkembangan remaja, ketika lingkungan bersifat positif maka remaja akan berkembangan kearah yang positif sesuai aturan dan norma yang berlaku begitupun sebaliknya (Setijaningsih et al., 2019).

Hasil berbeda penelitian yang dilakukan pada siswa kelas X dan XI SMA Kota Padang dengan jumlah sampel 158 orang menemukan tidak ada hubungan bermakna antara tingkat pengetahuan tentang kesehatan reproduksi dengan perilaku seksual remaja ( $\mathrm{p}=0,841)$ (Mahmudah \& Lestari, 2016). Penelitian yang dilakukan diseluruh SMA/sederajat di Kecamatan Siberut Selatan dengan jumlah sampel 126 responden, menemukan tidak ada hubungan tingkat pengetahuan dengan perilaku seksual pranikah remaja ( $\mathrm{p}=0,257)$ (Yolanda \& Kurniadi, 2019).

Penelitian yang dilakukan sebelumnya menunjukkan sikap remaja mengenai seksualitas berperan terhadap perilaku seksual pranikah. Penelitian yang dilakukan di SMK Patria Gadingrejo dengan sampel 134 siswa, menemukan ada hubungan sikap dengan perilaku seksual pada remaja $(\mathrm{p}=0.000)$. Hal ini disebabkan oleh banyak faktor, antara lain masih rendahnya pengetahuan yang dimiliki remaja mengenai seksualitas. Selain itu, meskipun banyak remaja mengetahui tentang seks akan tetapi faktor budaya yang melarang membicarakan mengenai seksualitas di depan umum karena dianggap 
tabu, akhirnya akan dapat menyebabkan pengetahuan remaja tentang seks tidak lengkap dimana para remaja hanya mengetahui cara dalam melakukan hubungan seks tetapi tidak mengetahui dampak yang akan muncul akibat perilaku seks tersebut (Kumalasari, 2016).

Penelitian lain yang dilakukan di beberapa SMA di Kota Semarang dengan 271 sampel, menemukan ada hubungan yang bermakna $(\mathrm{p}=0,0001)$ antara sikap mengenai seksualitas dengan perilaku seksual pranikah remaja (Naja \& Agushybana, 2017). Penelitian yang dilakukan sebelumnya menunjukkan pengaruh teman sebaya berperan terhadap perilaku seksual pranikah remaja. Penelitian yang dilakukan di SMAN 6 Makassar dengan jumlah sampel sebanyak 274 siswa, menemukan bahwa ada hubungan teman sebaya terhadap perilaku seksual berisiko siswa $(p=0,000, \varphi=0,339)$ (Masni \& Hamid, 2018).

Penelitian lain yang dilakukan di SMA " $X$ " Kota Tegal dengan jumlah sampel 254 responden, menemukan peran teman sebaya memiliki hubungan yang signifikan $(\mathrm{p}<0,05)$ dengan perilaku seksual pranikah pada remaja SMA. Remaja yang melakukan perilaku seksual pranikah beresiko dan didukung oleh teman sebaya lebih besar 1,75 kali dibandingkan dengan yang tidak mendukung (Pratiwi et al., 2018).

Penelitian yang dilakukan Setijaningsih et al., (2019) menyatakan bahwa remaja yang tidak berpacaran memiliki persepsi yang positif dibandingkan dengan remaja yang berpacaran mengenai perilaku seks pranikah. Menurut Winata (2014) remaja yang tidak berpacaran cenderung memiliki persepsi positif dikarenakan mereka beranggapan bahwa pacaran memiliki banyak dampak negatifnya, selain itu pacaran merupakan sarana seks bebas yang dapat mengakibatkan kejadian kehamilan di luar nikah, hal itu dikarenakan pada zaman sekarang ini gaya berpacaran remaja banyak mengarah kepada hal-hal yang berbau seksualitas seperti berciuman, berpelukan, petting dan melakukan hubungan seks itu sendiri.

Remaja seringkali memiliki persepsi yang salah mengenai makna pacaran. Remaja menganggap bahwa masa pacaran merupakan masa ketika seseorang boleh mencintai dan dicintai oleh pasangannya dan mengungkapkan rasa cinta atau kasih sayang dengan berbagai cara, seperti memberi bunga, berpelukan, berciuman, bahkan melakukan hubungan seksual. Hubungan seksual pranikah menjadi fenomena yang saat ini banyak dilakukan oleh remaja yang berpacaran (Wongso, 2014).

Remaja yang berpacaran memiliki persepsi negatif dibandingkan dengan remaja yang tidak berpacaran dikarenakan mereka yang berpacaran sangat beresiko melakukan bentuk-bentuk seks pranikah seperti berpelukan, berciuman, petting dan melakukan hubungan seksual dibandingkan dengan remaja yang tidak berpacaran. Hal itu dibuktikan dengan parameter yang telah diteliti bawasannya remaja yang tidak berpacaran mengganggap boleh berpegangan tangan dan berpelukan dengan pasangan namun remaja yang berpacaran menganggap lebih dari itu sampai ketahap berciuman, hal ini merupakan salah satu perbedaan persepsi antara remaja yang berpacaran dengan remaja yang tidak berpacaran, selain itu mereka memiliki persepsi yang salah mengenai makna pacaran itu sendiri, mereka menganggap ketika berpacaran maka sepasang kekasih dapat melakukan apapun sesuai dengan keinginan mereka yang pada akhirnya akan merugikan mereka sendiri jika mereka tidak dapat mengendalikan hasrat dan dorongan seksual mereka dengan baik (Setijaningsih et al., 2019).

Seseorang yang memiliki sikap positif akan menunjukkan perilaku yang positif pula. Maka, dalam hal ini kecenderungan remaja berperilaku seksual akan dipengaruhi oleh sikapnya, yaitu suka dan tidak suka, atau setuju dan tidak setuju (Pawestri et al., 2013). 
Remaja yang secara psikologis sedang mengalami kematangan seksual akan mengembangkan hubungan khusus dengan lawan jenis atau going steady, sangat rentan dengan berbagai pengalaman yang dapat mempengaruhi mereka untuk melakukan perilaku seksual pranikah. Hal ini karena pada masa pacaran, mahasiswa akan mencapai suatu perasaan aman (feelings of security) dengan pasangannya. Feelings of security ini dapat menimbulkan suatu keintiman seksual pada mereka (azwar, 2015).

\section{SIMPULAN}

Simpulan dari hasil penelitian yang telah dilakukan peneliti yaitu ada hubungan secara signifikan antara pacar terhadap perilaku seks pranikah pada siswa-siswi SMPN 16 di Kecamatan Sukajadi.

\section{SARAN}

\section{Bagi Sekolah}

Penelitian ini dapat dijadikan pertimbangan untuk memasukkan kurikulum kesehatan reproduksi diberikan kepada siswa-siswi secara mendalam.

Bagi Siswa

Siswa dapat meningkatkan pengetahuan tentang seks pranikah, pemahaman tingkat agama, dengan mencari informasi yang baik serta dukungan keluarga sangat penting.

\section{DAFTARPUSTAKA}

Agung, A. (2016). Keperjakaan dan Keperawanan Generasi Milineal. https://tirto.id/keperjakaan-dankeperawanan-generasi-milenial-bEYw

Agustina, R. (2013). Perilaku Pacaran Siswi Sekolah Menengah Pertama Negeri (SMPN) $X$ Banyumanik di Kota Semarang. Skripsi. eprints.undip.ac.id

Azinar, M. (2013). Perilaku Seksual Pranikah Berisiko terhadap Kehamilan Tidak Diinginkan. Jurnal Kesehatan Masyarakat, 8(2), 153-160. https://journal.unnes.ac.id/nju/index.php/kemas/article/view/2639

Azwar, S. (2015). Penyusunan Skala Psikologi. Yogyakarta: Pustaka Pelajar

Evi, E., Nasir, S., \& Suriah, S. (2013). Perilaku Seksual pada Remaja yang Berpacaran di SMA Negeri 2 Kairatu Kabupaten Seram Bagian Barat. Jurnal MKMI, 250-256

Febriawati, H., Padila, P., \& Anita, B. (2018). Pendidikan Seksual Remaja Melalui Poskesja. Jurnal Pengabdian Masyarakat Bumi Raflesia, 1(1), 45-53. http://jurnal.umb.ac.id/index.php/pengabdianbumir/article/view/193

Fuad, F. (2010). Remaja dan Perilaku Seks. Jakarta: EGC

Guruh, P. (2015). Hubungan antara Pengetahuan Kesehatan Reproduksi dan Sikap Seksualitas dengan Perilaku Pacaran Pada Pelajar SLTA di Kota Semarang. Universitas Muhammadiyah Surakarta

Hamzah, B., \& Hamzah, R. (2020). Determinan Perilaku Seksual Pranikah pada Remaja (Studi Kasus di SMA Negeri 1 Kotamobagu). Bina Generasi: Jurnal Kesehatan, 11(2), 9-13. DOI: https://doi.org/10.35907/bgjk.v11i2.147

Kemenkes RI. (2015). Infodatin Situasi Kesehatan Reproduksi Remaja

Kisriyati, K. (2013). Hubungan Seksual dalam Pacaran Bagi Remaja di Kecamatan Baureno Kabupaten Bojonegoro. Jurnal Paradigma, 1(1), 1-8

Kumalasari, K. (2016). Hubungan Pengetahuan dan Sikap dengan Perilaku Seksual pada Siswa SMK. Stikes 'Aisyiyah Pringsewu

Lestari, S. (2016). Psikologi Keluarga. Jakarta: Prenadamedia Group 
Mahmudah, Y., \& Lestari, Y. (2016). Faktor-Faktor yang Berhubungan dengan Perilaku Seksual Remaja di Kota Padang. Jurnal Kesehatan Andalas, 5(2), 448455. DOI: https://doi.org/10.25077/jka.v5i2.538

Masni, M., \& Hamid, S. F. (2018). Determinan Perilaku Seksual Berisiko pada Remaja Makassar (Studi Kasus Santri Darul Arqam Gombara dan SMAN 6). Media Kesehatan Masyarakat Indonesia Universitas Hasanuddin, 14(1), 68-77. https://doi.org/10.30597/mkmi.v14i1.3699

Meilani, N., \& Setiyawati, N. (2017). Pengaruh Tingkat Pengetahuan dan Sikap tentang Pacaran terhadap Perilaku Pacaran pada Siswa SMA di Yogyakarta. Kesehatan Ibu dan Anak, 11(2), 15-19. DOI: https://doi.org/10.29238/kia.v11i2.34

Mustofa, S. B., \& Winarni, P. (2010). Faktor yang Mempengaruhi Perilaku Seks Pranikah Mahasiswa di Pekalongan Tahun 2009-2010. Jurnal Kesehatan Reproduksi, $1(1)$, $32-41$. http://ejournal.litbang.kemkes.go.id/index.php/kespro/article/view/1321

Naja, Z. S., \& Agushybana, A. M. (2017). Hubungan Pengetahuan, Sikap mengenai Seksualitas dan Paparan Media Sosial dengan Perilaku Seksual Pranikah pada Remaja Dibeberapa SMA Kota Semarang Triwulan II Tahun 2017. Jurnal Kesehatan Masyarakat, 5(4). https://doi.org/10.1017/CBO9781107415324.004

Ningtyas, S. D. Y. (2012). Hubungan antara Self Control dengan Internet Addiction pada Mahasiswa. Educational Psychology Journal, 1(1), 25-30

Nurhayati, A., \& Fajar, N. A. (2017). Determinan Perilaku Seksual Pranikah pada Remaja SMA Negeri 1 Indralaya Utara. Jurnal Ilmu Kesehatan Masyarakat, 8(2), 83-90. http://repository.unsri.ac.id/id/eprint/28988

Padila, P. (2015). Asuhan Keperawatan Maternitas 1. Yogyakarta: Nuha Medika

Pawestri, N. S., Wardani, R. S., \& Sonna, M. (2013). Pengetahuan, Sikap dan Perilaku Remaja tentang Seks Pra Nikah. Jurnal Keperawatan Maternitas PPNI, 1(1), 4654

PBKI. (2011). Survey PKBI Semarang tentang Angka Kejadian Seks Pranikah. Semarang: PKBI JATENG

Pratiwi, B. A., Febriawati, H., Angraini, W., Yanuari, R., \& Padila, P. (2019). Determinant Fakctors of Early Marriage in Bengkulu Tengah. Pakistan Journal of Medical and Health Sciences 13(1), 202-205. https://www.researchgate.net/publication/333432110_Determinant_fakctors_of_ear ly_marriage_in_Bengkulu_Tengah

Pratiwi, N. A., Padmawati, R. S., \& Wahyuni, B. (2018). Peran Teman Sebaya terhadap Perilaku Seksual Pranikah pada Remaja SMA di Kota Tegal. Jurnal Berita Kedokteran Masyarakat, 34(5), 3-10. https://doi.org/10.22146/bkm.37719

Rahyani, K. Y., Utarini, A., Wilopo, S. A., \& Hakimi, M. (2012). Perilaku Seks Pranikah Remaja. Jurnal Kesmas, Jurnal Kesehatan Masyrakat Nasional, 7(4), 180-185. DOI: http://dx.doi.org/10.21109/kesmas.v7i4.53

Rosdarni, R., \& Dasuki, D. W. (2015). Pengaruh Faktor Personal terhadap Perilaku Seksual Pranikah pada Remaja. Jurnal Kesehatan Masyarakat Nasional, 9(3), 214221. http://journal.fkm.ui.ac.id/index.php/kesmas/article/view/567

Rusmiati, D. \& Hastono, S. P. (2015). Sikap Remaja terhadap Keperawanan dan Perilaku Seksual dalam Berpacaran. Jurnal Kesehatan Masyarakat Nasional, 10(1), 29-36. DOI: http://dx.doi.org/10.21109/kesmas.v10i1.815

Santrock, J. W. (2010). Adolescent: Perkembangan Remaja. Jakarta: Erlangga

Sarwono, S. (2011). Psikologi remaja. Jakarta: Rajawali Pers 
Sarwono, S., \& Sarlito, W. (2015). Psikologi remaja. Jakarta: PT Raja Grafindo Persada

Setijaningsih, T., Hasanudin, H., \& Winarni, S. (2019). Persepsi antara Remaja yang Berpacaran dengan Remaja yang Tidak Berpacaran tentang Perilaku Seks Pranikah. Journal of Borneo Holistic Heatlh, 2(1), 1-16

Shaluhiyah, Z., Suryoputro, A., \& Setyawati, A. (2017). The Needs of Information Services on Reproductibe Health, STIs and HIV in Middle Adolescents. Jurnal Kesehatan Masyarakat Kesmas 12(2). https://journal.unnes.ac.id/nju/index.php/kemas/article/view/5366

Winata, F. H. H. (2014). Gaya Berpacaran Remaja di Sekolah Menengah Atas Katolik Diponegoro Blitar. Blitar: Politeknik Kesehatan Kemenkes Malang

Wongso, F. (2014). Peran Pacar bagi Emerging Adulthood Laki Laki. Jurnal Universitas Surabaya, 3(1). http://journal.ubaya.ac.id/index.php/jimus/article/view/1677/1368

Yolanda, R., \& Kurniadi, A. (2019). Faktor-faktor yang Berhubungan dengan Sikap Remaja terhadap Perilaku Seksual Pranikah di Kecamatan Siberut Selatan , Kepulauan Mentawai Tahun 2018. Jurnal Kesehatan Reproduksi, 10(1), 69-78. https://doi.org/10.22435/kespro.v10i1.2174.69-78 